\title{
What have we learned from the embryonic transcriptome?
}

\author{
Claude Robert* and Isabelle Gilbert \\ Département des sciences animales, Centre de recherche en biologie de la reproduction, Institut sur la \\ nutrition et les aliments fonctionnels, Université Laval, Québec, QC, Canada
}

\begin{abstract}
During the last decade, transcriptome profiling has emerged as an efficient approach to describe and study cellular functions. The potential to survey transcript abundance for all genes offers promise to shed light on mammalian early embryogenesis. Furthermore, the report of aberrant phenotypes following the application of reproductive technologies also fueled the need to understand how embryos react, cope and adapt to their surrounding microenvironment. So far, the atypical nature of early blastomeres and the drastic transitions through which embryogenesis progresses posed and still pose numerous technical challenges such as to correctly interpret the natural fluctuation in total RNA and proteins contents. Although tedious, these technical considerations are important for data soundness and interpretation. In this review, we examine a number of transcriptomic surveys performed on blastocysts and demonstrate that several consistent observations have transpired that alter the conceptual issues regarding the definition of embryonic normalcy. Moreover, the need to complement the study of gene expression with profiling epigenomic marks is opening new perspectives that will also be discussed.
\end{abstract}

\section{Introduction}

Regulation and modification of gene expression are what allow every living being to respond to varying cellular needs and to adapt to a changing environment. Modification is observable mainly in terms of gene transcription products (i.e. messenger RNA) and translation products (i.e. proteins). It is therefore expected that the study of gene product expression level will be indicative of physiological state. The roles of transcriptional regulators including factors acting on gene promoters and their complement of gene enhancer and silencer elements in driving expression have been known for decades. An additional level of complexity identified more recently is known as epigenetics: modification of gene expression driven by dynamic chromatin configurations and a multitude of nuclear phenomena. Gene expression and its regulation have become the focus of many studies, and are at the core of our efforts to understand early development, that is, the makeup, physiology and outcome of the early embryo. 
In the early 2000s, advances in genomics and bioinformatics provided the opportunity to apply a more comprehensive methodology than conventional gene candidate approaches. The term "transcriptomics" was coined as a reference to methodologies capable to surveying the transcript population with a scope well superior than what is offered by RT-qPCR. The current definition of transcriptomics does not reach consensus where a restrictive view is limiting the term to samples processed on Next Generation Sequencing platforms that surveys most transcripts (a selection of transcripts based on size and/or presence of poly $(\mathrm{A})$ tail is generally performed during library preparation) while a more lenient acceptance in term usage includes large but partial surveys. Here transcriptomics refers to the study of total or partial set of transcripts from a tissue or a cell population. In fact, the development of high-throughput platforms for the measurement of gene expression has caused a paradigm shift in the enunciation of initial hypotheses, broadening the initial premises to include the concept that differences in physiological state among experimental specimens are reflected in gene product abundance (primarily mRNA) and ultimately the molecular pathways being regulated through gene expression. In other words, by observing deviations in RNA abundance, we can identify the physiological processes underlying phenotype or developmental outcome.

The first high-throughput platforms dedicated to the survey of mRNA were cDNA microarrays developed and used successfully to estimate the transcriptional contents of early embryos (Ko et al. 2000, Tanaka et al. 2000, Carter et al. 2003, Sirard et al. 2005, Misirlioglu et al. 2006, Somers et al. 2006). The study of early mammalian development always has been and remains technically challenging, since embryos are a scant source of biological material. However, unlike protein profiles, the transcriptome can be amplified starting from minute amounts of material, and this approach has gained wide popularity and is now routine practice. The challenges of limited sample size have thus been met for transcriptome profiling and science is now turning its attention to single-cell transcriptome analysis (Tang et al. 2011, Katayama et al. 2013).

It is becoming clear that as technical challenges are overcome and the more we analyse cellular gene expression, the more complex developmental physiology seems to be. For instance, while microarrays have provided means of interrogating all known genes in a sample, thus raising the possibility of unexpected findings such as the involvement of gene pathways, not previously known to be active during early development, they are now criticized for their limitation of addressing only the transcript fragments corresponding to the oligo/probe set. This criticism has been addressed with the advent of next-generation sequencing (RNA-seq), which facilitates RNA sequencing, thus broadening the scope of the survey to include populations such as mRNA, miRNA, tRNA, LncRNA andrRNA (Wilhelm et al. 2008) Marioni et al. 2008.

Through Next-Generation RNA sequencing (RNA-seq), the complexity of the transcriptome has become obvious, since in addition to differential gene expression intensities, higher level of complex features such as multiple splicing variants within or outside the protein-coding region and an entire population of novel transcripts with yet unknown functions have emerged. We have only begun to scratch the surface of the potential implications of alternative splicing for protein diversity, of the stabilization and destabilization of RNA, or of these uncharacterized transcripts as modulators of embryonic phenotypes.

The aim of this review is to provide a current perspective on the strides that have been made in transcriptomic studies of mammalian embryos. The challenge to integrate transcriptomics information into a physiological context will also be discussed.

RNA abundance in early development and its correlation with physiological functions

One of the first observations made when studying RNA management in early blastomeres is that gene regulation falls outside of the textbook model in which expression relies on synthesis 
of pre-mRNA transcripts that are spliced, capped and polyadenylated before transport from the nucleus to the rough endoplasmic reticulum, where ribosomes translate the functional mRNA to polypeptides that are subsequently processed in the cytoplasm. Based on this standard chain of events, protein production is expected to reflect cell mRNA content. However, oocytes and the blastomeres rely on maternal RNA reserves accumulated during oogenesis to sustain protein synthesis, especially during the first cell divisions, which occur while nuclear transcription is minimal, if not absent (Plante et al. 1994, Memili et al. 1998, Lodde et al. 2008). This initial period of transcriptional silence is species-specific (Braude et al. 1988, Poueymirou \& Schultz 1989, Memili et al. 1998). It is believed that a large proportion of the maternal RNA reserves are never translated and is instead simply decomposed (Bachvarova \& De Leon 1980, Su et al. 2007, Ma et al. 2013). The explanation for such apparent wastage of a major expenditure of energy and immobilization of material resources is unknown. In mice, destruction of maternal RNA is a an essential prelude to embryonic genome activation (Ma et al. 2013). In non-mammalian model organisms, degradation of maternal RNA has been shown to start with binding of microRNA to specific sequences in the $3^{\prime}$ untranslated region during pre-embryonic genome activation (Tadros \& Lipshitz 2005, Giraldez et al. 2006, Lund et al. 2009). In large mammals, embryonic genome activation occurs several cell cycles later than in mice, maternal RNA stores are utilized to sustain protein synthesis during this extended period of transcriptional silence, and maternal reserves are used and degraded more gradually (Gilbert et al. 2009). It remains very difficult to draw any conclusion regarding the biological implications of transcript abundance where endogenous reserves and the possibility of RNA degradation prior to translation are involved (Gilbert et al. 2009).

Mammalian somatic cells generally contain $20-30$ pg of total RNA, of which $1-5 \%$ is mRNA. In the case of oocytes and early blastomeres, these figures are very different: A bovine fully grown GV stage oocyte contains around $340 \mathrm{pg}$ of total RNA with a proportion of $18 \%$ of mRNA whereas a bovine blastocyst contains 2,350 pg of total RNA (Figure 1) (Gilbert et al. 2009). Oocytes accumulate RNA reserves during their growth and these maternal stocks are used to sustain protein synthesis until embryonic genome activation (Clegg \& Piko 1982, Piko \& Clegg 1982, Bachvarova et al. 1985, Paris \& Richter 1990, Paynton \& Bachvarova 1994). This implies that cells contain large quantities of dormant RNA and that transcript abundance may not be indicative of protein synthesis. This is true for the entire pre-embryonic genome activation period, after which gene expression becomes more like in somatic cells. When RNA reserves are present, no scenario can be excluded: transcripts and their corresponding proteins may both be abundant, or transcripts may be abundant while the proteins are completely absent (Pennetier et al. 2004, Vigneault et al. 2009). In addition, in embryos in which genome activation occurs days after fertilization (i.e. in large mammals), ribosomal RNA profiles are very different from those of somatic cells. Microelectrophoretic profiles of total RNA obtained prior to embryonic genome activation show the two large ribosomal RNA molecules present in ratios far from the 18S: $28 \mathrm{~S}$ theoretical maximum of 2.5 used as an indicator of sample quality in somatic cells (Gilbert et al. 2009). The physiological implications of this atypical ribosomal RNA content are still unclear. During the stages prior to embryonic genome activation, $28 \mathrm{~S}$ RNA is detected in low amounts, and considering that it is the major component of the 605 ribosomal subunit, this may influence cell capacity for translation and/or ribosome turnover rate (Gilbert et al. 2009).

It is still unclear how dormant maternal RNA is recruited and sent either for protein synthesis or for breakdown. Clear evidence of the "closed-loop" model proposed in Xenopus and involving cytoplasmic polyadenylation-element-binding protein and Maskin to control RNA recruitment and translation (McGrew \& Richter 1990, Kim \& Richter 2008, Martineau et al. 2008, Radford et al. 2008) has not been shown in mammals. Differences could exist between the strategies 
that amphibians and mammals devised as they evolved to manage maternal RNA. In Xenopus, embryonic genome activation occurs when the number of cells reaches 4,000-8,000, which corresponds to 12-13 divisions and occurs within seven hours (Newport \& Kirschner 1982b, Newport \& Kirschner 1982a). For such demanding and rapid recruitment of maternal RNA, mechanisms of storage may differ from those of mammals.

Conserved mechanisms of maternal RNA storage include poly(A) tail removal and reelongation, the former rendering the molecule dormant and the latter required for recruitment. However, stored RNA are not completely deadenylated and variable length in poly(A) tails is observed (Gray \& Wickens 1998, Gohin et al. 2014). Prior to embryonic genome activation, the transcript population is therefore composed of molecules bearing a very wide range of poly(A) tail lengths (Lequarre et al. 2004). Figure 1 provides an overview of the levels of RNA found in this developmental window. Oligo-dT may be used during sample processing to select different subpopulations of transcripts (Robert 2010). Since protein synthesis requires transcripts bearing a poly(A) tail, this use of oligo-dT might introduce a bias against stored transcripts. Whether or not this occurs is uncertain since the extent of tail shortening and lengthening required for RNA storage and recruitment is unknown and clear segregation based on tail length might not exist. Data need to be interpreted with caution since any comparison of treatments showing lower abundance of RNA during the maternal stage could be attributed to loss due to protein synthesis, to different poly(A) tail lengths or to increased rates of decay without translation.

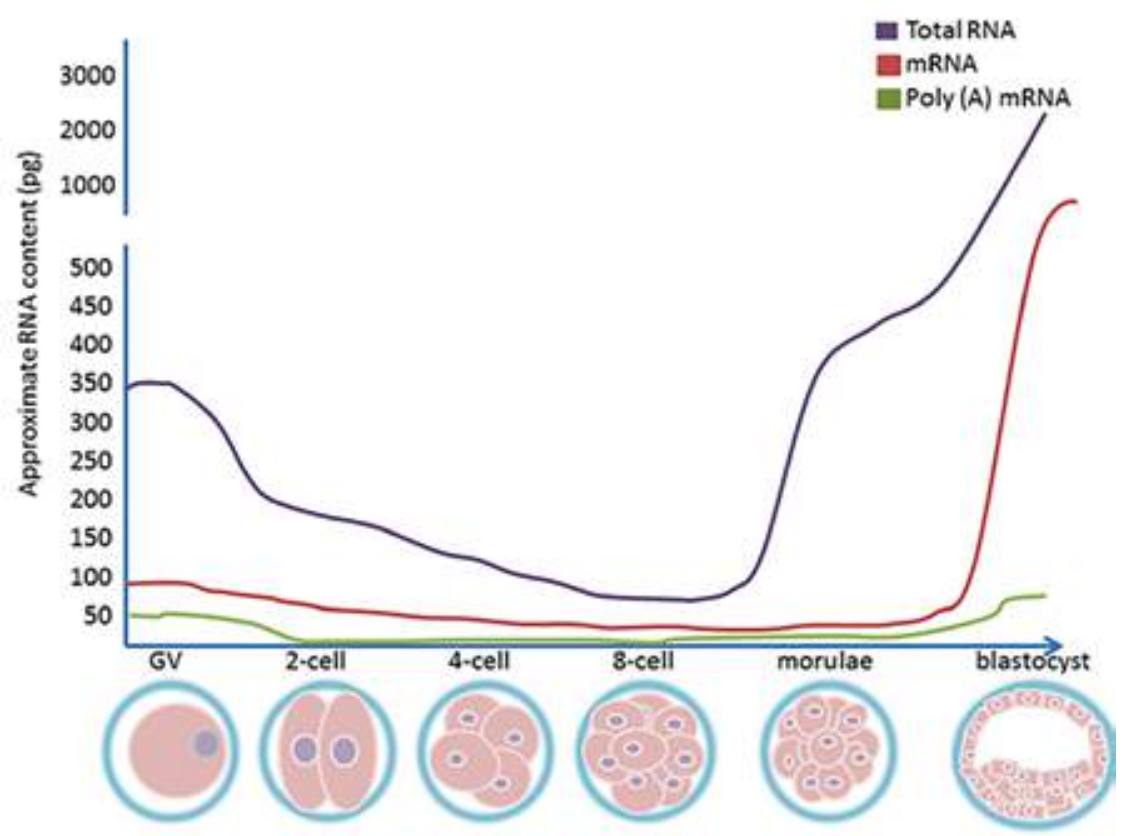

Figure 1. Schematic illustration of the different categories of RNA found in bovine oocytes and in embryos during the early stages of development

Even more challenging than interpreting transcript abundance prior to embryonic genome activation (no matter the technological platform) is the comparison of transcript abundance across developmental stages. Since each developmental stage differs in terms of cell number and size and RNA and protein content, there are no points of reference to which data can be easily interpreted in its physiological context. Prior to embryonic genome activation, cell number is irrelevant since the RNA content of a blastomere represents a subdivision of the 
maternal RNA pool present at the previous stage. Following genome activation, cell number matters but it is still difficult to abandon the concept of the embryo as the biological unit and switch to accounting for cell numbers, because of a lack of reference for the interpretation of transcript level per blastomere.

The dynamics of early embryogenesis pose many challenges for RNA profiling and data interpretation (Figure 2). Sample preparation methodology and data normalization can influence measurements and data interpretation profoundly (Gilbert et al. 2010). Over the years, spiking samples with exogenous transcripts has emerged as the most appropriate way to normalize datasets, since in a situation of overall reduction of cellular RNA content, all assumed housekeeping candidates will follow the same trend no matter how many reference genes are used, and thus contribute to data over-normalization (Robert 2010). A similar situation also occurs in high-throughput RNA profiling by microarrays and RNA sequencing (RNA-seq), since most normalization algorithms are based on leveling the mean or median between samples, which differ naturally throughout the various stages of development.

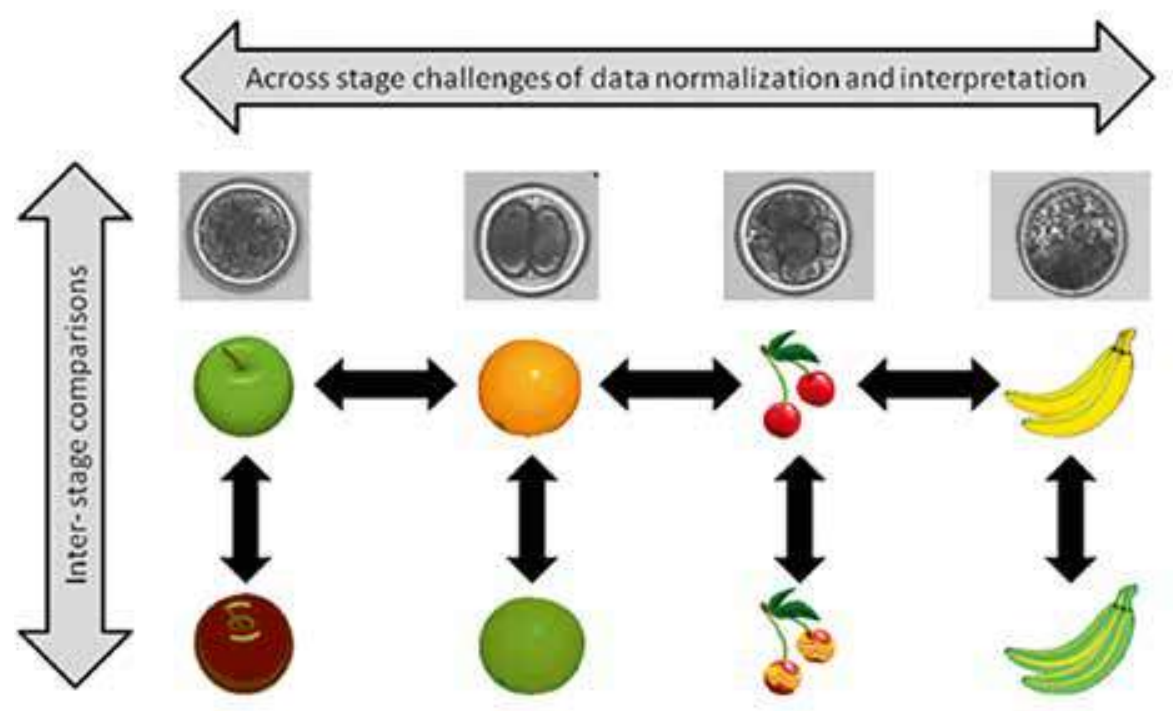

Figure 2. Different challenges arise when comparing samples within a developmental stage or across developmental stages. Due to large differences between embryos at different stages in terms of cell content (RNA, DNA, proteins, lipids, etc.), cell number and transcriptional potential, inter-stage comparison poses several challenges for data normalization and interpretation. In inter-stage comparisons, similar specimens will be compared, thus providing a more direct interpretation of treatment effects.

Elevated amounts of dormant RNA definitely hinder our attempts to describe mammalian early embryo physiology based on the transcriptome. It is well accepted that protein profiling would be a better-suited approach. However, overall profiling and identification of proteins still requires hundreds to thousands of oocytes or early embryos (Coenen et al. 2004, Massicotte et al. 2006, Berendt et al. 2009, Han et al. 2010). As an alternative, one efficient strategy for distinguishing between active and stored $\mathrm{mRNA}$ is to isolate subpopulations present in polyribosomal fractions (Potireddy et al. 2006, Chen et al. 2011, Scantland et al. 2011). Assuming that messenger RNA bound to polyribosomes is being processed for translation, it is presumed to be representative of gene activity and hence of the underlying physiological status. In mouse studies, comparison 
of the GV stage to MII oocytes by polyribosomal fractionation has provided insight into the reduction of translation potential, while the comparison of zygotes and 2-cell embryos has provided information about the proteins required for embryonic genome activation (Potireddy et al. 2006, Chen et al. 2011).

\section{The post-embryonic genome activation transcriptome}

Most of the transcriptomic surveys carried out during pre-hatching development have been performed on blastocysts, since this is the last developmental stage that can be maintained in culture. So far, the main application for these RNA abundance measurements has been to describe the impact of assisted reproductive technologies on embryo physiology. In most studies, embryos obtained from oocytes fertilized in vitro have been compared to reference embryos collected in vivo. The need for better understanding of the impact of assisted reproductive technologies on early development grew from observations of greater prevalence of aberrant phenotypes in animals resulting from embryos produced in vitro or obtained from somatic cloning (Young et al. 1998, van Wagtendonk-de Leeuw et al. 2000, Gibbons et al. 2002, Smith et al. 2012), including enlarged placentas and fetuses in ruminants (Sinclair et al. 2000, De Sousa et al. 2001), abnormalities associated with increased prenatal loss and higher perinatal mortality, although these phenotypes may lead to perfectly sound offspring.

Earlier work aimed at identifying deviant gene expressions that could explain how early developmental stress translates into long-term consequences was conducted using RT-PCR (qualitative and quantitative) on candidate genes. Numerous studies have shown skewed responses to culture conditions. Impact on all types of molecular functions has been observed, including energetic metabolism, free radical management and synthesis of cell structural constituents (Wrenzycki et al. 1996, Wrenzycki et al. 1998, Niemann \& Wrenzycki 2000, Wrenzycki et al. 2001, Yaseen et al. 2001, Lazzari et al. 2002, Wrenzycki et al. 2002, Lonergan et al. 2003a, Lonergan et al. 2003b, Lonergan et al. 2003c). Nowadays, the use of microarrays and RNA sequencing provides a more comprehensive picture of gene activity. It is now clear, based on observation of gene expression in a broad array of cell functions, that embryos react to perturbations in their microenvironment (Carter et al. 2010, Cote et al. 2011, Cagnone et al. 2012, Gad et al. 2012b, Plourde et al. 2012a, Plourde et al. 2012b, Cagnone \& Sirard 2013, Cagnone \& Sirard 2014). Gene expression overall tends to be more active in blastocysts of embryos produced in vitro than in their in vivo counterparts. This is consistent with the observation that metabolically quiet embryos tend to have better developmental potential (Leese 2002, Leese et al. 2007). Furthermore, in vitro conditions also influence the kinetics of embryo development (Mingoti et al. 2011), suggesting the possibility of stimulating or accelerating development, in vitro. Although perhaps unrelated physiologically, cleavage rate and developmental competence appear to be correlated (Lechniak et al. 2008, Isom et al. 2012, Orozco-Lucero et al. 2014). The transcriptomes of embryos produced in different culture media have been compared in several studies (Cote et al. 2011, Cagnone et al. 2012, Plourde et al. 2012b, Cagnone \& Sirard 2013, Penagaricano et al. 2013, Cagnone \& Sirard 2014). We have found in our laboratory that culture conditions providing poor developmental rates in some cases unexpectedly produced blastocysts with a transcriptome more similar to the in vivo reference than did conditions that yielded the highest blastocyst rates (Cote et al. 2011). Furthermore, a treatment intended as a negative control in which embryos were produced in media without serum, BSA or any macromolecule provided a low blastocyst rate as expected, but an overall transcriptome similar to that observed for the best-yielding system (Cote et al. 
2011). In addition, low-yielding systems provided more consistent transcriptome profiles than did high-yield conditions (Cote et al. 2011). This is reflected in much greater morphological dispersion among embryo cohorts than is observed with high-yielding systems. Conceptual questions arose from these results (Figure 3): Does the stringency of low-yielding systems allow only highly competent embryos to survive while high-yielding systems keep compromised or deviant embryos alive? Would ill phenotypes be more frequent among blastocysts produced in high-yielding systems? Is optimization of in vitro conditions to obtain the highest blastocyst rates a justified goal? These questions remain unanswered.

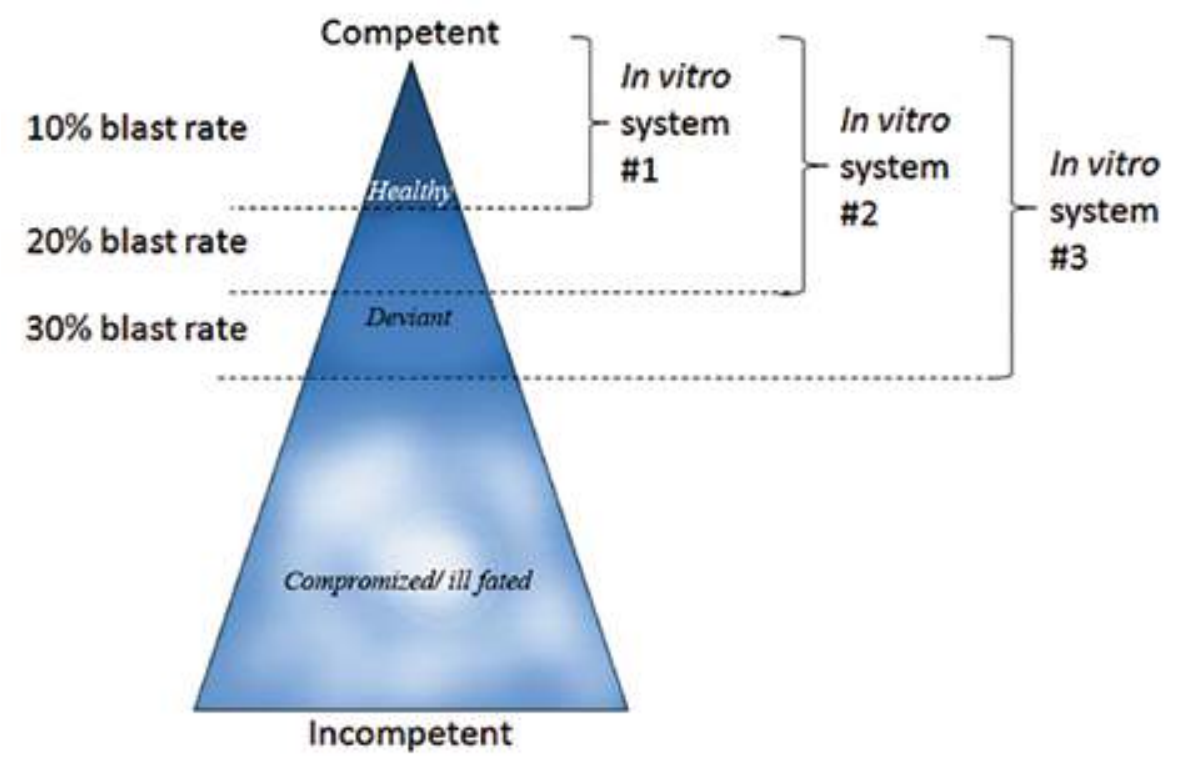

Figure 3. Intrinsic developmental potential is determined largely by the quality of the oocyte. Are observed differences between the performances of in vitro production systems merely indicative of stringency allowing only high-potential embryos to survive? Would the most competent oocytes reach the blastocyst stage in all systems or would the blastocysts yielded by different systems originate from oocytes with different characteristics?

It was also noted early in the study of the response of embryo transcriptomes to different assisted fertilization microenvironments that blastocyst cohort composition influenced the results. Some in vitro production systems produce cohorts that are more homogenous than others (Cote et al. 2011, Plourde et al. 2012b). In most studies, samples composed of a fixed number of pooled blastocysts are analysed. However, all blastocysts are not equal in terms of morphology and hence cell number, type (e.g. inner cell mass or trophectoderm) and viability. Comparing blastocysts of different morphological classes revealed important differences in transcriptome profile (Rekik et al. 2011). In addition, some culture conditions have been shown to skew the gender ratio and that male and female blastocysts exhibit large differences in gene expression (Bermejo-Alvarez et al. 2010, Garcia-Herreros et al. 2012). These observations presented a conundrum, since the most logical grouping of embryos for valid comparisons of in vitro treatments was according to morphology and gender. The treatment effects were thus confounded with effects due to these factors. Part of the solution to this problem would be to obtain transcriptome profiles of single blastocysts that had been sexed and morphologically classified. However, due to natural biological variance, this would require experimental designs with a larger number of biological replications in order to reach statistical significance, and 
this for both genders and all morphological classes. This would allow a more comprehensive description of embryo cohorts obtained from a treatment, but at extreme cost in terms of resources.

In some gene expression studies, a specific blastocyst subgroup defined on the basis of morphological characteristics may be of interest, for example expanded blastocysts when production of embryos of a quality sufficient for uterine transfer is the goal. The best culture conditions in this case are those that produce the greatest number of high-grade transferable embryos. In our experience, the comparison of stage-specific blastocysts greatly decreases the number of genes contributing to confounding effects that merely reflect the impact of the experimental treatments on embryo cohort sample heterogeneity (Plourde et al. 2012a, Plourde et al. 2012b).

\section{How do embryos cope with stress?}

One of the most comprehensive transcriptome profiling studies was a comparison of blastocysts on the basis of time spent in vitro or in vivo (Gad et al. 2012a). Early embryos were collected in vivo at different times post-insemination and their development was continued in vitro while embryos obtained from in vitro fertilization were placed in utero at various early developmental stages and then re-collected at the blastocyst stage for continued development. It was thus shown that extending the time in vitro led to affect genes implicated in lipid metabolism deviations and free radical management. These same authors have thoroughly reviewed the impact of culture conditions on transcript abundance (Gad et al. 2012b).

Many other large-scale gene expression studies that focused on the impact of media composition in culture systems support the conclusion that genes involved in lipid metabolism and free radical management are highly responsive cellular pathways in early embryos. For several years now, serum has been suspected of inducing abnormal offspring syndrome (Young et al. 2001, Lazzari et al. 2002) and is known to increase lipid accumulation in embryos (Crosier et al. 2001, McEvoy et al. 2001). Moreover, the stress caused by exposure to high levels of lipid affects the inflammatory response, while deviant lipid metabolism leads to decreased survival rates after cryopreservation (Rizos et al. 2003). Both oocytes and embryos are very sensitive to the lipid content of their microenvironment and certain fatty acids are particularly detrimental to embryo development (Leroy et al. 2005, Shehab-El-Deen et al. 2009, Leroy et al. 2010, Van Hoeck et al. 2013, Cagnone \& Sirard 2014). In addition to bringing a completely new perspective to the impact of maternal nutrition on fertility, these results add emphasis to the influence of the microenvironment on embryo metabolism.

Increased concentrations of glucose cause blastomeres to shift their energetic metabolism from the standard mitochondrial aerobic pathway to the anaerobic fermentative pathway terminating with lactic acid, a sign of stress similar to the Warburg effect observed in cancer cells (Cagnone et al. 2012). It was shown more than a decade ago that the presence of serum not only causes lipid accumulation but also reduces mitochondrial capacity (Abe et al. 2002). Our studies of the impact of culture conditions based on strict comparison of the transcriptomes of morphologically staged blastocysts (early blastocysts) indicate similar effects on lipid metabolism and mitochondrial function (Plourde et al. 2012b). However, mitochondrial function was affected only when embryos were produced from oocytes collected from slaughterhouse ovaries. When oocytes were collected in vivo by trans-vaginal pick up, mitochondrial function was not affected and blastocyst rates were greatly increased (Plourde et al. 2012b).

It appears overall that metabolic stress in embryos is sensed primarily by mitochondria, which respond by switching energy pathways, and in turn influences cell lipid content and 
free radical management, possibly triggering apoptosis. It has already been proposed that embryos of superior quality have greater mitochondrial capacity, based on higher mitochondrial DNA content (St John et al. 2004, El Shourbagy et al. 2006, Van Blerkom 2011, Stigliani et al. 2013). Several studies based on different methodological approaches and with different perspectives on embryo quality all converge to the conclusion that viability is highly dependent on mitochondrial status, which is highly sensitive to environmental conditions. We believe that proper mitochondrial function begins in the oocyte and translates into higher developmental potential supported by a stable and relatively quiescent metabolic state.

A window of sensitivity to stress exists around the time of embryo genome activation (Gad et al. 2012a). This corresponds to the time at which mitochondria switch from the immature shape found in the oocyte (known to be inefficient for oxidative phosphorylation due mainly to the limited number of cristae) to a more mature cylindrical form (Crocco et al. 2011). It also coincides with an increase in the efficiency of energy production from glucose (Rieger et al. 1992). During these important cytoplasmic events, the nuclear genome activates first by initiating transcription in the nucleolus, which is the site of ribosomal RNA production (Hyttel 2001). As mentioned, prior to genome activation, the embryo has an atypical 18S: 28S RNA ratio and subsequently acquires a ratio close to that of somatic cells (Gilbert et al. 2009).

Activation also involves a major genomic reprogramming that is done to erase the extremely specific programs of the gametes and allow the very plastic program of undifferentiated (totipotent or stem) cells to begin. The mechanisms by which genomic reprogramming occurs are currently the focus of many studies worldwide and are beyond the scope of the present review (for recent reviews on this topic see (Kohli \& Zhang 2013, Seisenberger et al. 2013). This reprogramming is effected through complete reorganization of the epigenetic architecture, including DNA methylation and histone modifications, and coincides with the longest cell cycle of pre-hatching development (36.25 \pm 15.05 hours in cattle (Lequarre et al. 2003)) and culminates in major activation of transcription.

\section{Window of sensitivity and mechanisms of coping with stress}

One of the most striking observations to emerge from comparing the transcriptome of embryos produced under different conditions is that the embryonic RNA population is composed of a large contingent of long non-coding (Inc) molecules (Robert et al. 2011, Zhang et al. 2012). Furthermore, we found that this class of transcripts is the most profoundly affected by culture conditions (Cote et al. 2011, Plourde et al. 2012b). Even IncRNA originating from the mitochondrial genome was among the candidates most affected. The in vitro microenvironment was also associated with the presence of IncRNA that was undetectable in blastocysts obtained in vivo. To our knowledge, no such variance has ever been observed for a protein-encoding transcript.

The abundance of these uncharacterized transcripts in blastomeres far exceeds the prevalence observed in somatic cells as published by the Encode Project (Harrow et al. 2012). The source of IncRNA has been determined from transcriptional events occurring in intergenic or intronic regions as well as from the strand opposite the protein-coding sequence, thus corresponding to natural antisense RNA (Khalil et al. 2009, Hawkins \& Morris 2010, Li \& Ramchandran 2010). These events have often been considered as transcriptional noise (Hangauer et al. 2013). However, emerging evidence suggests that this dark matter is important and plays a crucial role in nearly all cellular processes from nuclear transcription to epigenetic remodeling to translation control (Fatica \& Bozzoni 2014). It may also be crucial for the development and maintenance of stem cell potency (van Leeuwen \& Mikkers 2010, Guttman et al. 2011, Fatica \& Bozzoni 2014). 
The involvement of IncRNA in embryo physiology remains unknown. Does it result from transcriptional leakage arising from the permissive state characterizing embryonic stem cells? Stem cell transcription favors shorter gene transcripts (Mercer et al. 2011) due probably to a shorter cell cycle length. Is the extended cell cycle that marks the activation of the embryonic genome more prone to transcriptional errors? Are deviations in IncRNA abundance observed at the blastocyst stage indicative of denatured epigenetic marks? These questions remain unanswered.

\section{Integration of data already available may hold the key to the future}

Over the past decade, transcriptome profiling studies have been numerous. Most of these studies have focused on a handful of candidates for further characterization. The bulk of the data is still of interest insofar as each study was designed to address one or a few questions but combined with other datasets could serve to increase the statistical power to highlight trends in embryo response. Although different methodological platforms can lead to data incompatibility and increased noise, by considering the limitations regarding platform compatibility and sample composition, it may be possible to generate a reference base of embryo general responsiveness. This is important, since the concept of embryo normalcy has yet to be defined (Figure 4). For instance, to what extent does deviant management of free radicals lead to a deviant phenotype? Normalcy must reside within an interval and some stresses may be more challenging than others to embryo viability. Such a definition would provide a rational basis for improving conditions in order to produce embryos of superior quality.

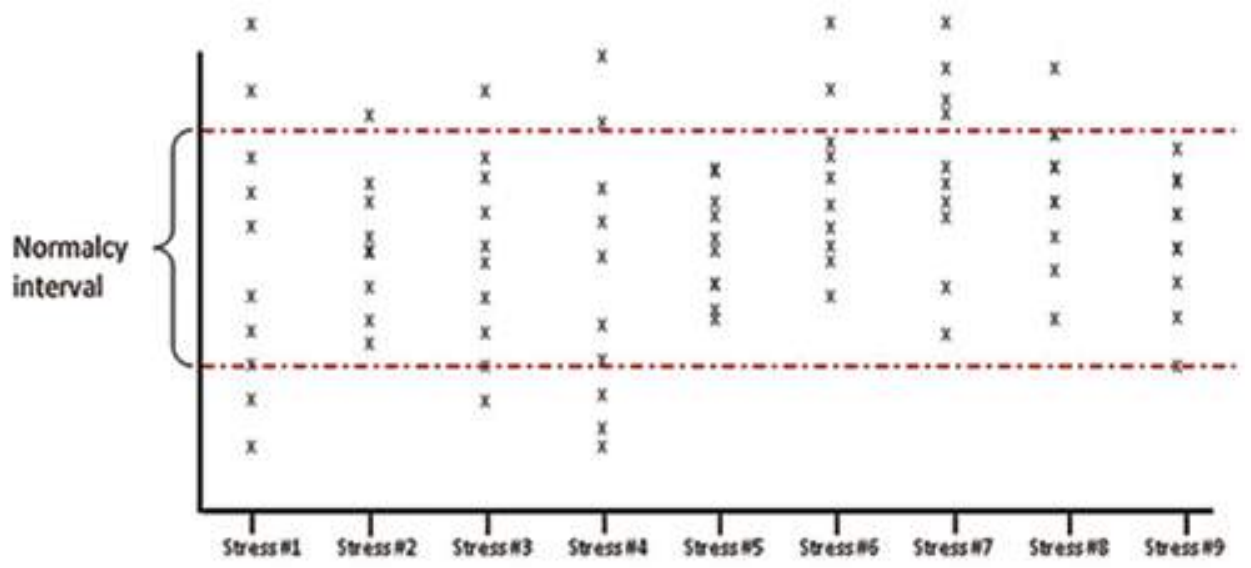

Figure 4. Given that blastocysts react to their environment, it is expected that they will modify their gene expression in response to different environmental insults represented by the different stresses along the $X$ axis. Deviant gene expression could fall within a normalcy interval (red dots lines) that does not translate into peak phenotypes or it could induce long-term effects. The current challenge is to distinguish transient adaptive responses from deviations with potential long-term impact.

One of the main challenges ahead is to define how observed deviations in gene expression translate into physiology. Since it is now well established that embryos both react and adapt to changes in their microenvironment and that their response to the stress of assisted fertilization involves changes in gene expression level, the next step is to distinguish between transient responses and those that have a long-term impact. One way to accomplish this might be 
to integrate the different layers of genomic data including transcript abundance and DNA methylation. Each of these types of information alone may be limited in usefulness while a combined picture could lead to new insight. For instance, would a deviant gene expression accompanied by altered DNA methylation at the same locus be indicative of long-term impact whereas absence of impact on DNA methylation would be more indicative of a transient response driven by transcription factors? The study of DNA methylation alone is proving to be more complex than anticipated, since methylation marks are distributed throughout the entire genome, which spans 100 times more nucleotides than the protein-coding regions. Interpretation of DNA methylation data is currently challenging to say the least. Sorting datasets in terms of extent and position of methylation marks in relation to the corresponding transcript levels may prove helpful.

\section{Conclusion}

In conclusion, transcriptome profiling of early embryos remains technically challenging, especially when the survey is conducted across developmental stages. Blastocyst gene expression profiling has provided nonetheless valuable insight into how embryos cope with their microenvironment. The possibility of adding epigenetic information will raise new opportunities to refine our knowledge of embryonic physiology. A link very likely exists between the biological functions of mRNA, IncRNA and DNA methylation. Known interactions include that involving IncRNA Xist, which drives $X$ chromosome inactivation in females, resulting in extensive DNA methylation and shutdown of nearly all genes on this chromosome (Froberg et al. 2013, Lessing et al. 2013). Even more relevant, dysregulation in the interplay between expression of protein encoding genes, IncRNA transcription and DNA methylation is responsible for many imprinting-related disorders such as large offspring syndrome in ruminants and Beckwith-Wiedemann and Silver-Russell syndromes in humans (Chiesa et al. 2012, Singh et al. 2012, Soejima \& Higashimoto 2013). With such a wealth of information within reach, the prospects for studying and defining in fine detail the characteristics of an early embryo destined to become a healthy individual are very promising.

\section{References}

Abe H, Yamashita S, Satoh T \& Hoshi H 2002 Accumulation of cytoplasmic lipid droplets in bovine embryos and cryotolerance of embryos developed in different culture systems using serum-free or serum-containing media. Mol Reprod Dev 61 57-66.

Bachvarova R \& De Leon V 1980 Polyadenylated RNA of mouse ova and loss of maternal RNA in early development. Dev Biol 74 1-8.

Bachvarova R, De Leon V, Johnson A, Kaplan G \& Paynton BV 1985 Changes in total RNA, polyadenylated RNA, and actin mRNA during meiotic maturation of mouse oocytes. Dev Biol 108 325-331.

Berendt FJ, Frohlich T, Bolbrinker P, Boelhauve M, Gungor T, Habermann FA, Wolf E \& Arnold GJ 2009 Highly sensitive saturation labeling reveals changes in abundance of cell cycle-associated proteins and redox enzyme variants during oocyte maturation in vitro. Proteomics 9 550-564.
Bermejo-Alvarez P, Rizos D, Rath D, Lonergan P \& Gutierrez-Adan A 2010 Sex determines the expression level of one third of the actively expressed genes in bovine blastocysts. Proc Natl Acad Sci U S A 107 3394-3399.

Braude P, Bolton V \& Moore S 1988 Human gene expression first occurs between the four- and eight-cell stages of preimplantation development. Nature 332 459-461.

Cagnone G \& Sirard MA 2014 The impact of exposure to serum lipids during in vitro culture on the transcriptome of bovine blastocysts. Theriogenology 81 712-722 e713.

Cagnone GL, Dufort I, Vigneault C \& Sirard MA 2012 Differential gene expression profile in bovine blastocysts resulting from hyperglycemia exposure during early cleavage stages. Biol Reprod 8650.

Cagnone GL \& Sirard MA 2013 Transcriptomic signature to oxidative stress exposure at the time of embryonic genome activation in bovine blastocysts. Mol Reprod Dev 80 297-314. 
Carter F, Rings F, Mamo S, Holker M, Kuzmany A, Besenfelder U, Havlicek V, Mehta JP, Tesfaye D, Schellander K \& Lonergan P 2010 Effect of elevated circulating progesterone concentration on bovine blastocyst development and global transcriptome following endoscopic transfer of in vitro produced embryos to the bovine oviduct. Biol Reprod 83 707-719.

Carter MG, Piao Y, Dudekula DB, Qian Y, VanBuren V, Sharov AA, Tanaka TS, Martin PR, Bassey UC, Stagg CA, Aiba K, Hamatani T, Matoba R, Kargul GJ \& Ko MS 2003 The NIA cDNA project in mouse stem cells and early embryos. C R Biol 326 931-940.

Chen J, Melton C, Suh N, Oh JS, Horner K, Xie F, Sette C, Blelloch R \& Conti M 2011 Genome-wide analysis of translation reveals a critical role for deleted in azoospermia-like (Dazl) at the oocyte-to-zygote transition. Genes Dev 25 755-766.

Chiesa N, De Crescenzo A, Mishra K, Perone L, Carella M, Palumbo O, Mussa A, Sparago A, Cerrato F, Russo S, Lapi E, Cubellis MV, Kanduri C, Cirillo Silengo M, Riccio A \& Ferrero GB 2012 The KCNQ1OT1 imprinting control region and non-coding RNA: new properties derived from the study of Beckwith-Wiedemann syndrome and Silver-Russell syndrome cases. Hum Mol Genet 21 10-25.

Clegg KB \& Piko L 1982 RNA synthesis and cytoplasmic polyadenylation in the one-cell mouse embryo. Nature 295 343-344.

Coenen K, Massicotte L \& Sirard MA 2004 Study of newly synthesized proteins during bovine oocyte maturation in vitro using image analysis of two-dimensional gel electrophoresis. Mol Reprod Dev 67 313-322.

Cote I, Vigneault C, Laflamme I, Laquerre J, Fournier E, Gilbert I, Scantland S, Gagne D, Blondin P \& Robert C 2011 Comprehensive cross production system assessment of the impact of in vitro microenvironment on the expression of messengers and long non-coding RNAs in the bovine blastocyst. Reproduction 142 99-112.

Crocco M, Alberio RH, Lauria L \& Mariano MI 2011 Effect of serum on the mitochondrial active area on developmental days 1 to 4 in in vitro-produced bovine embryos. Zygote 19 297-306.

Crosier AE, Farin PW, Dykstra MJ, Alexander JE \& Farin CE 2001 Ultrastructural morphometry of bovine blastocysts produced in vivo or in vitro. Biol Reprod 64 1375-1385.

De Sousa PA, King T, Harkness L, Young LE, Walker SK \& Wilmut I 2001 Evaluation of gestational deficiencies in cloned sheep fetuses and placentae. Biol Reprod 65 23-30.

El Shourbagy SH, Spikings EC, Freitas M \& St John JC 2006 Mitochondria directly influence fertilisation outcome in the pig. Reproduction 131 233-245.

Fatica A \& Bozzoni I 2014 Long non-coding RNAs: new players in cell differentiation and development. Nat Rev Genet 15 7-21.

Froberg JE, Yang L \& Lee JT 2013 Guided by RNAs: $\mathrm{X}$-inactivation as a model for IncRNA function. J Mol Biol 425 3698-3706.

Gad A, Hoelker M, Besenfelder U, Havlicek V, Cinar U, Rings F, Held E, Dufort I, Sirard MA, Schellander K \& Tesfaye D 2012a Molecular mechanisms and pathways involved in bovine embryonic genome activation and their regulation by alternative in vivo and in vitro culture conditions. Biol Reprod 87100.

Gad A, Schellander K, Hoelker M \& Tesfaye D 2012b Transcriptome profile of early mammalian embryos in response to culture environment. Anim Reprod Sci 134 76-83.

Garcia-Herreros M, Aparicio IM, Rath D, Fair T \& Lonergan P 2012 Differential glycolytic and glycogenogenic transduction pathways in male and female bovine embryos produced in vitro. Reprod Fertil Dev 24 344352.

Gibbons J, Arat S, Rzucidlo J, Miyoshi K, Waltenburg R, Respess D, Venable A \& Stice S 2002 Enhanced survivability of cloned calves derived from roscovitinetreated adult somatic cells. Biol Reprod 66 895-900.

Gilbert I, Scantland S, Sylvestre EL, Dufort I, Sirard MA \& Robert C 2010 Providing a stable methodological basis for comparing transcript abundance of developing embryos using microarrays. Mol Hum Reprod 16 601-616.

Gilbert I, Scantland S, Sylvestre EL, Gravel C, Laflamme I, Sirard MA \& Robert C 2009 The dynamics of gene products fluctuation during bovine pre-hatching development. Mol Reprod Dev 76 762-772.

Giraldez AJ, Mishima Y, Rihel J, Grocock RJ, Van Dongen S, Inoue K, Enright AJ \& Schier AF 2006 Zebrafish MiR430 promotes deadenylation and clearance of maternal mRNAs. Science 312 75-79.

Gohin M, Fournier E, Dufort I \& Sirard MA 2014 Discovery, identification and sequence analysis of RNAs selected for very short or long poly A tail in immature bovine oocytes. Mol Hum Reprod 20 127-138.

Gray NK \& Wickens M 1998 Control of translation initiation in animals. Annu Rev Cell Dev Biol 14 399-458.

Guttman M, Donaghey J, Carey BW, Garber M, Grenier JK, Munson G, Young G, Lucas AB, Ach R, Bruhn L, Yang X, Amit I, Meissner A, Regev A, Rinn JL, Root DE \& Lander ES 2011 lincRNAs act in the circuitry controlling pluripotency and differentiation. Nature 477 295-300.

Han Z, Liang CG, Cheng Y, Duan X, Zhong Z, Potireddy S, Moncada C, Merali S \& Latham KE 2010 Oocyte spindle proteomics analysis leading to rescue of chromosome congression defects in cloned embryos. J Proteome Res 9 6025-6032.

Hangauer MJ, Vaughn IW \& McManus MT 2013 Pervasive transcription of the human genome produces thousands of previously unidentified long intergenic noncoding RNAs. PLoS Genet 9 e1003569.

Harrow J, Frankish A, Gonzalez JM, Tapanari E, Diekhans M, Kokocinski F, Aken BL, Barrell D, Zadissa A, Searle S, Barnes I, Bignell A, Boychenko V, Hunt T, Kay M, Mukherjee G, Rajan J, Despacio-Reyes G, Saunders G, Steward C, Harte R, Lin M, Howald C, Tanzer A, Derrien T, Chrast J, Walters N, Balasubramanian S, Pei B, Tress M, Rodriguez JM, Ezkurdia I, van Baren J, Brent M, Haussler D, Kellis M, Valencia A, Reymond A, Gerstein M, Guigo R \& Hubbard TJ 2012 GENCODE: the reference human genome annotation for The ENCODE Project. Genome Res 22 1760-1774. 
Hawkins PG \& Morris KV 2010 Transcriptional regulation of Oct4 by a long non-coding RNA antisense to Oct4pseudogene 5. Transcription 1 165-175.

Hyttel P 2001 Nucleolus formation in pre-implantation cattle and swine embryos. Ital J Anat Embryol 106 109-117.

Isom SC, Li RF, Whitworth KM \& Prather RS 2012 Timing of first embryonic cleavage is a positive indicator of the in vitro developmental potential of porcine embryos derived from in vitro fertilization, somatic cell nuclear transfer and parthenogenesis. Mol Reprod Dev 79 197-207.

Katayama S, Tohonen V, Linnarsson S \& Kere J 2013 SAMstrt: statistical test for differential expression in single-cell transcriptome with spike-in normalization. Bioinformatics 29 2943-2945.

Khalil AM, Guttman M, Huarte M, Garber M, Raj A, Rivea Morales D, Thomas K, Presser A, Bernstein BE, van Oudenaarden A, Regev A, Lander ES \& Rinn JL 2009 Many human large intergenic noncoding RNAs associate with chromatin-modifying complexes and affect gene expression. Proc Natl Acad Sci U S A 106 11667-11672.

Kim JH \& Richter JD 2008 Measuring CPEB-mediated cytoplasmic polyadenylation-deadenylation in Xenopus laevis oocytes and egg extracts. Methods Enzymol 448 119-138.

Ko MS, Kitchen JR, Wang X, Threat TA, Hasegawa A, Sun T, Grahovac MJ, Kargul GJ, Lim MK, Cui Y, Sano Y, Tanaka T, Liang Y, Mason S, Paonessa PD, Sauls AD, DePalma GE, Sharara R, Rowe LB, Eppig J, Morrell C \& Doi H 2000 Large-scale cDNA analysis reveals phased gene expression patterns during preimplantation mouse development. Development 127 1737-1749.

Kohli RM \& Zhang Y 2013 TET enzymes, TDG and the dynamics of DNA demethylation. Nature 502 472-479.

Lazzari G, Wrenzycki C, Herrmann D, Duchi R, Kruip T, Niemann H \& Galli C 2002 Cellular and molecular deviations in bovine in vitro-produced embryos are related to the large offspring syndrome. Biol Reprod $\mathbf{6 7}$ 767-775.

Lechniak D, Pers-Kamczyc E \& Pawlak P 2008 Timing of the first zygotic cleavage as a marker of developmental potential of mammalian embryos. Reprod Biol 8 23-42.

Leese HJ 2002 Quiet please, do not disturb: a hypothesis of embryo metabolism and viability. Bioessays 24 845-849.

Leese HJ, Sturmey RG, Baumann CG \& McEvoy TG 2007 Embryo viability and metabolism: obeying the quiet rules. Hum Reprod 22 3047-3050.

Lequarre AS, Marchandise J, Moreau B, Massip A \& Donnay I 2003 Cell cycle duration at the time of maternal zygotic transition for in vitro produced bovine embryos: effect of oxygen tension and transcription inhibition. Biol Reprod 69 1707-1713.

Lequarre AS, Traverso JM, Marchandise J \& Donnay I 2004 Poly(A) RNA is reduced by half during bovine oocyte maturation but increases when meiotic arrest is maintained with CDK inhibitors. Biol Reprod 71 425-431.

Leroy JL, Van Hoeck V, Clemente M, Rizos D, GutierrezAdan A, Van Soom A, Uytterhoeven M \& Bols PE 2010 The effect of nutritionally induced hyperlipidaemia on in vitro bovine embryo quality. Hum Reprod 25 768-778.

Leroy JL, Vanholder T, Mateusen B, Christophe A, Opsomer
G, de Kruif A, Genicot G \& Van Soom A 2005 Nonesterified fatty acids in follicular fluid of dairy cows and their effect on developmental capacity of bovine oocytes in vitro. Reproduction 130 485-495.

Lessing D, Anguera MC \& Lee JT 2013 X chromosome inactivation and epigenetic responses to cellular reprogramming. Annu Rev Genomics Hum Genet 14 85-110.

Li K \& Ramchandran R 2010 Natural antisense transcript: a concomitant engagement with protein-coding transcript. Oncotarget 1 447-452.

Lodde V, Modina S, Maddox-Hyttel P, Franciosi F, Lauria A \& Luciano AM 2008 Oocyte morphology and transcriptional silencing in relation to chromatin remodeling during the final phases of bovine oocyte growth. Mol Reprod Dev 75 915-924.

Lonergan P, Rizos D, Gutierrez-Adan A, Fair T \& Boland MP 2003a Effect of culture environment on embryo quality and gene expression - experience from animal studies. Reprod Biomed Online 7 657-663.

Lonergan P, Rizos D, Gutierrez-Adan A, Moreira PM, Pintado B, de la Fuente J \& Boland MP 2003b Temporal divergence in the pattern of messenger RNA expression in bovine embryos cultured from the zygote to blastocyst stage in vitro or in vivo. Biol Reprod 69 1424-1431.

Lonergan P, Rizos D, Kanka J, Nemcova L, Mbaye AM, Kingston M, Wade M, Duffy P \& Boland MP 2003C Temporal sensitivity of bovine embryos to culture environment after fertilization and the implications for blastocyst quality. Reproduction 126 337-346.

Lund E, Liu M, Hartley RS, Sheets MD \& Dahlberg JE 2009 Deadenylation of maternal mRNAs mediated by miR-427 in Xenopus laevis embryos. RNA 15 2351-2363.

Ma J, Flemr M, Strnad H, Svoboda P \& Schultz RM 2013 Maternally recruited DCP1A and DCP2 contribute to messenger RNA degradation during oocyte maturation and genome activation in mouse. Biol Reprod 8811.

Marioni JC, Mason CE, Mane SM, Stephens M \& Gilad Y 2008 RNA-seq: an assessment of technical reproducibility and comparison with gene expression arrays. Genome Res 18 1509-1517.

Martineau Y, Derry MC, Wang X, Yanagiya A, Berlanga JJ, Shyu AB, Imataka H, Gehring K \& Sonenberg N 2008 Poly(A)-binding protein-interacting protein 1 binds to eukaryotic translation initiation factor 3 to stimulate translation. Mol Cell Biol 28 6658-6667.

Massicotte L, Coenen K, Mourot M \& Sirard MA 2006 Maternal housekeeping proteins translated during bovine oocyte maturation and early embryo development. Proteomics 6 3811-3820.

McEvoy TG, Robinson J] \& Sinclair KD 2001 Developmental consequences of embryo and cell manipulation in mice and farm animals. Reproduction 122 507-518.

McGrew LL \& Richter JD 1990 Translational control by cytoplasmic polyadenylation during Xenopus oocyte maturation: characterization of cis and trans elements and regulation by cyclin/MPF. EMBO / 9 3743-3751.

Memili E, Dominko T \& First NL 1998 Onset of transcription in bovine oocytes and preimplantation embryos. Mol Reprod Dev 51 36-41. 
Mercer TR, Wilhelm D, Dinger ME, Solda G, Korbie DJ, Glazov EA, Truong V, Schwenke M, Simons C, Matthaei KI, Saint R, Koopman P \& Mattick JS 2011 Expression of distinct RNAs from 3' untranslated regions. Nucleic Acids Res 39 2393-2403.

Mingoti GZ, Castro VS, Meo SC, Sa Barretto LS \& Garcia JM 2011 The effects of macromolecular and serum supplements and oxygen tension during bovine in vitro procedures on kinetics of oocyte maturation and embryo development. In Vitro Cell Dev Biol Anim 47 361-367.

Misirlioglu M, Page GP, Sagirkaya H, Kaya A, Parrish J, First NL \& Memili E 2006 Dynamics of global transcriptome in bovine matured oocytes and preimplantation embryos. Proc Natl Acad Sci U S A 103 18905-18910.

Newport J \& Kirschner M 1982a A major developmental transition in early Xenopus embryos: I. characterization and timing of cellular changes at the midblastula stage. Cell 30 675-686.

Newport J \& Kirschner M 1982b A major developmental transition in early Xenopus embryos: II. Control of the onset of transcription. Cell 30 687-696.

Niemann H \& Wrenzycki C 2000 Alterations of expression of developmentally important genes in preimplantation bovine embryos by in vitro culture conditions: implications for subsequent development. Theriogenology 53 21-34.

Orozco-Lucero E, Dufort I, Robert C \& Sirard MA 2014 Rapidly cleaving bovine two-cell embryos have better developmental potential and a distinctive mRNA pattern. Mol Reprod Dev 81 31-41.

Paris J \& Richter JD 1990 Maturation-specific polyadenylation and translational control: diversity of cytoplasmic polyadenylation elements, influence of poly(A) tail size, and formation of stable polyadenylation complexes. Mol Cell Biol 10 5634-5645.

Paynton BV \& Bachvarova R 1994 Polyadenylation and deadenylation of maternal mRNAs during oocyte growth and maturation in the mouse. Mol Reprod Dev 37 172-180.

Penagaricano F, Souza AH, Carvalho PD, Driver AM, Gambra R, Kropp J, Hackbart KS, Luchini D, Shaver RD, Wiltbank MC \& Khatib H 2013 Effect of maternal methionine supplementation on the transcriptome of bovine preimplantation embryos. PLoS One 8 e72302.

Pennetier S, Uzbekova S, Perreau C, Papillier P, Mermillod P \& Dalbies-Tran R 2004 Spatio-temporal expression of the germ cell marker genes MATER, ZAR1, GDF9, BMP15,andVASA in adult bovine tissues, oocytes, and preimplantation embryos. Biol Reprod 71 1359-1366.

Piko L \& Clegg KB 1982 Quantitative changes in total RNA, total poly(A), and ribosomes in early mouse embryos. Dev Biol 89 362-378.

Plante L, Plante C, Shepherd DL \& King WA 1994 Cleavage and $3 \mathrm{H}$-uridine incorporation in bovine embryos of high in vitro developmental potential. Mol Reprod Dev 39 375-383.

Plourde D, Vigneault C, Laflamme I, Blondin P \& Robert C 2012a Cellular and molecular characterization of the impact of laboratory setup on bovine in vitro embryo production. Theriogenology 77 1767-1778 e1761.

Plourde D, Vigneault C, Lemay A, Breton L, Gagne D,
Laflamme I, Blondin P \& Robert C 2012b Contribution of oocyte source and culture conditions to phenotypic and transcriptomic variation in commercially produced bovine blastocysts. Theriogenology 78 116-131 e111113.

Potireddy S, Vassena R, Patel BG \& Latham KE 2006 Analysis of polysomal mRNA populations of mouse oocytes and zygotes: dynamic changes in maternal mRNA utilization and function. Dev Biol 298 155-166.

Poueymirou WT \& Schultz RM 1989 Regulation of mouse preimplantation development: inhibition of synthesis of proteins in the two-cell embryo that require transcription by inhibitors of cAMP-dependent protein kinase. Dev Biol 133 588-599.

Radford HE, Meijer HA \& de Moor CH 2008 Translational control by cytoplasmic polyadenylation in Xenopus oocytes. Biochim Biophys Acta 1779 217-229.

Rekik W, Dufort I \& Sirard MA 2011 Analysis of the gene expression pattern of bovine blastocysts at three stages of development. Mol Reprod Dev 78 226-240.

Rieger D, Loskutoff NM \& Betteridge KJ 1992 Developmentally related changes in the uptake and metabolism of glucose, glutamine and pyruvate by cattle embryos produced in vitro. Reprod Fertil Dev 4 547-557.

Rizos D, Gutierrez-Adan A, Perez-Garnelo S, De La Fuente J, Boland MP \& Lonergan P 2003 Bovine embryo culture in the presence or absence of serum: implications for blastocyst development, cryotolerance, and messenger RNA expression. Biol Reprod 68 236-243.

Robert C 2010 Microarray analysis of gene expression during early development: a cautionary overview. Reproduction 140 787-801.

Robert C, Nieminen J, Dufort I, Gagne D, Grant JR, Cagnone G, Plourde D, Nivet AL, Fournier E, Paquet E, Blazejczyk M, Rigault P, Juge N \& Sirard MA 2011 Combining resources to obtain a comprehensive survey of the bovine embryo transcriptome through deep sequencing and microarrays. Mol Reprod Dev 78 651-664.

Scantland S, Grenon JP, Desrochers MH, Sirard MA, Khandjian EW \& Robert C 2011 Method to isolate polyribosomal mRNA from scarce samples such as mammalian oocytes and early embryos. BMC Dev Biol 118.

Seisenberger S, Peat JR, Hore TA, Santos F, Dean W \& Reik W 2013 Reprogramming DNA methylation in the mammalian life cycle: building and breaking epigenetic barriers. Philos Trans $R$ Soc Lond B Biol Sci 36820110330.

Shehab-El-Deen MA, Leroy JL, Maes D \& Van Soom A 2009 Cryotolerance of bovine blastocysts is affected by oocyte maturation in media containing palmitic or stearic acid. Reprod Domest Anim 44 140-142.

Sinclair KD, Young LE, Wilmut I \& McEvoy TG 2000 Inutero overgrowth in ruminants following embryo culture: lessons from mice and a warning to men. Hum Reprod 15 Suppl 5 68-86.

Singh P, Lee DH \& Szabo PE 2012 More than insulator: multiple roles of CTCF at the H19-lgf2 imprinted domain. Front Genet 3214. 
Sirard MA, Dufort I, Vallee M, Massicotte L, Gravel C, Reghenas H, Watson AJ, King WA \& Robert C 2005 Potential and limitations of bovine-specific arrays for the analysis of mRNA levels in early development: preliminary analysis using a bovine embryonic array. Reprod Fertil Dev 17 47-57.

Smith LC, Suzuki J, Jr., Goff AK, Filion F, Therrien J, Murphy BD, Kohan-Ghadr HR, Lefebvre R, Brisville AC, Buczinski S, Fecteau G, Perecin F \& Meirelles FV 2012 Developmental and epigenetic anomalies in cloned cattle. Reprod Domest Anim 47 Suppl 4 107-114.

Soejima H \& Higashimoto K 2013 Epigenetic and genetic alterations of the imprinting disorder BeckwithWiedemann syndrome and related disorders. J Hum Genet 58 402-409.

Somers J, Smith C, Donnison M, Wells DN, Henderson H, Mcleay L \& Pfeffer PL 2006 Gene expression profiling of individual bovine nuclear transfer blastocysts. Reproduction 131 1073-1084.

St John JC, Lloyd RE, Bowles EJ, Thomas EC \& El Shourbagy S 2004 The consequences of nuclear transfer for mammalian foetal development and offspring survival. A mitochondrial DNA perspective. Reproduction 127 631-641.

Stigliani S, Anserini P, Venturini PL \& Scaruffi P 2013 Mitochondrial DNA content in embryo culture medium is significantly associated with human embryo fragmentation. Hum Reprod 28 2652-2660.

Su YQ, Sugiura K, Woo Y, Wigglesworth K, Kamdar S, Affourtit J \& Eppig JJ 2007 Selective degradation of transcripts during meiotic maturation of mouse oocytes. Dev Biol 302 104-117.

Tadros W \& Lipshitz HD 2005 Setting the stage for development: mRNA translation and stability during oocyte maturation and egg activation in Drosophila. Dev Dyn 232 593-608.

Tanaka TS, Jaradat SA, Lim MK, Kargul GJ, Wang X, Grahovac MJ, Pantano S, Sano Y, Piao Y, Nagaraja R, Doi H, Wood WH, 3rd, Becker KG \& Ko MS 2000 Genomewide expression profiling of mid-gestation placenta and embryo using a 15,000 mouse developmental cDNA microarray. Proc Natl Acad Sci U S A 97 9127-9132.

Tang F, Lao K \& Surani MA 2011 Development and applications of single-cell transcriptome analysis. Nat Methods 8 S6-11.

Van Blerkom J 2011 Mitochondrial function in the human oocyte and embryo and their role in developmental competence. Mitochondrion 11 797-813.

Van Hoeck V, Rizos D, Gutierrez-Adan A, Pintelon I, Jorssen E, Dufort I, Sirard MA, Verlaet A, Hermans N, Bols PE \& Leroy JL 2013 Interaction between differential gene expression profile and phenotype in bovine blastocysts originating from oocytes exposed to elevated nonesterified fatty acid concentrations. Reprod Fertil Dev.

van Leeuwen S \& Mikkers H 2010 Long non-coding RNAs: Guardians of development. Differentiation 80 175-183. van Wagtendonk-de Leeuw AM, Mullaart E, de Roos AP, Merton JS, den Daas JH, Kemp B \& de Ruigh L 2000 Effects of different reproduction techniques: AI MOET or IVP, on health and welfare of bovine offspring. Theriogenology 53 575-597.

Vigneault C, McGraw S \& Sirard MA 2009 Spatiotemporal expression of transcriptional regulators in concert with the maternal-to-embryonic transition during bovine in vitro embryogenesis. Reproduction 137 13-21.

Waddington CH 1942 The epigenotype. Endeavour 1 18-20.

Waddington $\mathbf{C H} 2012$ The epigenotype. 1942. Int J Epidemiol 41 10-13.

Wilhelm BT, Marguerat S, Watt S, Schubert F, Wood V, Goodhead I, Penkett CJ, Rogers J \& Bahler J 2008 Dynamic repertoire of a eukaryotic transcriptome surveyed at single-nucleotide resolution. Nature 453 1239-1243.

Wrenzycki C, Herrmann D, Carnwath JW \& Niemann H 1996 Expression of the gap junction gene connexin43 (Cx43) in preimplantation bovine embryos derived in vitro or in vivo. J Reprod Fertil 108 17-24.

Wrenzycki C, Herrmann D, Carnwath JW \& Niemann H 1998 Expression of RNA from developmentally important genes in preimplantation bovine embryos produced in TCM supplemented with BSA. J Reprod Fertil 112 387-398.

Wrenzycki C, Herrmann D, Keskintepe L, Martins A, Jr., Sirisathien S, Brackett B \& Niemann H 2001 Effects of culture system and protein supplementation on mRNA expression in pre-implantation bovine embryos. Hum Reprod 16 893-901.

Wrenzycki C, Lucas-Hahn A, Herrmann D, Lemme E, Korsawe K \& Niemann H 2002 In vitro production and nuclear transfer affect dosage compensation of the X-linked gene transcripts G6PD, PGK, and Xist in preimplantation bovine embryos. Biol Reprod 66 127134.

Yaseen MA, Wrenzycki C, Herrmann D, Carnwath JW \& Niemann H 2001 Changes in the relative abundance of mRNA transcripts for insulin-like growth factor (IGF-I and IGF-II) ligands and their receptors (IGF-IR/IGF-IIR) in preimplantation bovine embryos derived from different in vitro systems. Reproduction 122 601-610.

Young LE, Fernandes K, McEvoy TG, Butterwith SC, Gutierrez CG, Carolan C, Broadbent PJ, Robinson JJ, Wilmut I \& Sinclair KD 2001 Epigenetic change in IGF2R is associated with fetal overgrowth after sheep embryo culture. Nat Genet 27 153-154.

Young LE, Sinclair KD \& Wilmut I 1998 Large offspring syndrome in cattle and sheep. Rev Reprod 3 155-163.

Zhang B, Penagaricano F, Chen H \& Khatib H 2012 Novel transcripts and alternatively spliced genes are associated with early development in bovine embryos. Animal 6 1199-1205. 
